Western University

Scholarship@Western

Aboriginal Policy Research Consortium International (APRCi)

2012

\title{
Indigenous free prior informed consent: a case for self determination in World Heritage nomination processes
}

Robert James Hales

John Rynne

Cathy Howlett

Jay Devine

Vivian Hauser

Follow this and additional works at: https://ir.lib.uwo.ca/aprci

Part of the Other Sociology Commons

Citation of this paper:

Hales, Robert James; Rynne, John; Howlett, Cathy; Devine, Jay; and Hauser, Vivian, "Indigenous free prior informed consent: a case for self determination in World Heritage nomination processes" (2012). Aboriginal Policy Research Consortium International (APRCi). 170

https://ir.lib.uwo.ca/aprci/170 
This article was downloaded by: [University of Western Ontario]

On: 18 November 2012, At: 08:01

Publisher: Routledge

Informa Ltd Registered in England and Wales Registered Number: 1072954 Registered

office: Mortimer House, 37-41 Mortimer Street, London W1T 3J H, UK

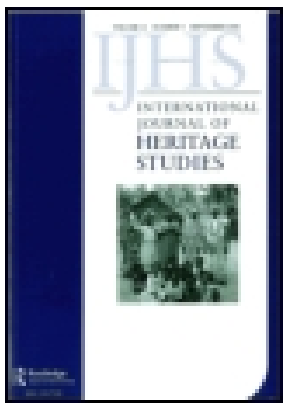

\section{International J ournal of Heritage Studies}

Publication details, including instructions for authors and subscription information:

http:// www.tandfonline.com/loi/ rjhs20

\section{Indigenous free prior informed consent: a case for self determination in World Heritage nomination processes}

Robert J ames Hales ${ }^{a}$, J ohn Rynne ${ }^{b}$, Cathy Howlett ${ }^{b}$, Jay Devine ${ }^{b} \&$ Vivian Hauser ${ }^{b}$

a Department of Tourism Leisure Hotel and Sport Management, Griffith University, Gold Coast, Australia

${ }^{b}$ School of Environment, Griffith University, Brisbane, Australia Version of record first published: 01 Mar 2012.

To cite this article: Robert J ames Hales, J ohn Rynne, Cathy Howlett, J ay Devine \& Vivian Hauser (2012): Indigenous free prior informed consent: a case for self determination in World Heritage nomination processes, International J ournal of Heritage Studies, DOI: $10.1080 / 13527258.2011 .654236$

To link to this article: http:// dx.doi.org/ 10.1080/ 13527258.2011.654236

\section{iFirst}

\section{PLEASE SCROLL DOWN FOR ARTICLE}

Full terms and conditions of use: http://www.tandfonline.com/page/terms-andconditions

This article may be used for research, teaching, and private study purposes. Any substantial or systematic reproduction, redistribution, reselling, loan, sub-licensing, systematic supply, or distribution in any form to anyone is expressly forbidden.

The publisher does not give any warranty express or implied or make any representation that the contents will be complete or accurate or up to date. The accuracy of any instructions, formulae, and drug doses should be independently verified with primary sources. The publisher shall not be liable for any loss, actions, claims, proceedings, demand, or costs or damages whatsoever or howsoever caused arising directly or indirectly in connection with or arising out of the use of this material. 


\title{
Indigenous free prior informed consent: a case for self determination in World Heritage nomination processes
}

\author{
Robert James Hales ${ }^{\mathrm{a} *}$, John Rynne ${ }^{\mathrm{b}}$, Cathy Howlett ${ }^{\mathrm{b}}$, Jay Devine ${ }^{\mathrm{b}}$ and Vivian \\ Hauser $^{\mathrm{b}}$ \\ ${ }^{a}$ Department of Tourism Leisure Hotel and Sport Management, Griffith University, Gold \\ Coast, Australia; ${ }^{b}$ School of Environment, Griffith University, Griffith University, Brisbane, \\ Australia
}

(Received 17 November 2011; final version received 22 December 2011)

\begin{abstract}
Free prior informed consent is a critical concept in enacting the rights of Indigenous People according to the United Nations Declaration on the Rights of Indigenous Peoples. This paper outlines a case for the inclusion of free prior informed consent in World Heritage nomination processes and examines issues that are problematic when enacting free prior informed consent. Case research was used to analyse current issues in the potential nomination of certain areas of Cape York Peninsula, Australia. The authors' reflexive engagement within this case offers insights into the praxis of developing a World Heritage nomination consent process. The outcomes of this research were: preconditions need to be addressed to avoid self-exclusion by indigenous representative organisations; the nature of consent needs to account for issues of representation and Indigenous ways of decision making; the power of veto needs to have formal recognition in the nomination process; and prioritising self-determination within free prior informed consent ensures the intent of the United Nations Declaration on the Rights of Indigenous Peoples. The paper contributes to the human rights agenda of Indigenous People and conservation management processes by helping address the issues that will be raised during a World Heritage nomination process.
\end{abstract}

Keywords: free prior informed consent; Indigenous; World Heritage; Cape York Peninsula

\section{Introduction}

Free prior informed consent (FPIC) has become a principle underpinning the international human rights agenda for Indigenous People (United Nations 2010a, 2010b) and is exemplified in the 2007 United Nations Declaration on the Rights of Indigenous Peoples (United Nations 2007). Within the declaration, the concept of FPIC is a key principle that potentially enables Indigenous People to exercise more power in negotiations over proposals that directly affect them.

FPIC can affect conservation management. The importance of involvement of Indigenous People through joint or co-conservation management arrangements in protected areas has been recognised at an international level increasingly over the past 15 years (Langton et al. 2005, Borrini-Feyerabend et al. 2006, Colchester et al.

*Corresponding author. Email: r.hales@griffith.edu.au 
2008, Berkes 2009, Lockwood 2010, United Nations 2011). That is, a critical aspect of co-management that occurs at the initial stage of negotiating potential management plans is the consent of Indigenous People to those arrangements. From the perspective of consent of Indigenous People in the co-management of protected areas, there are a number of directives that give guidance on Indigenous consent in conservation management. Some of the more important directives include: various decisions made by parties in the conferences on the Convention on Biological Diversity (CBD 1992), resolutions and recommendations on Indigenous People adopted at the 2008 World Conservation Congress (International Union for Conservation of Nature [IUCN] 2008); the Dana Declaration (Brosius 2004) and the IUCN-UNESCO Guidelines for protected area managers on Sacred Natural Sites (Wild and Mcleod 2009). These directives emphasise that long-term success of conservation needs the involvement of Indigenous People in management practices, and that a commonality of objectives is important in ensuring rights of Indigenous People are upheld and conservation imperatives are achieved.

Nevertheless, Indigenous People, typically the most impacted by the establishment of protected areas, commonly do not participate in the design and management of protected areas as these directives require (Perrault et al. 2006, West et al. 2006). Indeed, FPIC has not been specifically adopted in UNESCO's guidelines for engaging Indigenous People in World Heritage nomination processes (Disko 2010, United Nations 2011). Additionally, the principles of FPIC are largely absent from the International Council on Monuments and Sites (ICOMOS) procedures. ICOMOS is the organisation empowered by UNESCO under the World Heritage Convention to undertake cultural values assessment of World Heritage nominated sites and evaluates the involvement of stakeholders (including Indigenous representative bodies) associated with maintaining cultural values in the management plans for a site. This is assuming that Indigenous People have been acknowledged in World Heritage site assessments. The concept of a 'natural' site in the nomination process is a contested one in that if a site is nominated as a natural site Indigenous People are often ignored in the assessment process (Disko 2010). In brief, because FPIC is not included in the nomination procedures, the standards and obligations expected by the United Nations Declaration on the Rights of Indigenous Peoples remain largely unfulfilled in the field of natural and cultural heritage management in areas of high conservation value (United Nations 2011).

Thus, the purpose of this paper is to evaluate how FPIC can be incorporated into World Heritage nomination processes, as articulated within the United Nations Declaration on the Rights of Indigenous Peoples (2007). Specifically, the researchers argue that FPIC needs to be included in World Heritage nomination process, but the philosophical and practical issues that emerge from the ambiguities of the implementation of FPIC principles also need to be addressed. We identify ways for FPIC to be included in World Heritage nomination processes that will have the effect of enhancing the rights of Indigenous People who are affected by World Heritage Listing. The research contributes to the fields of Indigenous studies and conservation management because the adoption of FPIC by nation states in a variety of settings has been lacking (United Nations 2010a, 2010b).

The paper has three parts. A review of the literature develops how elements of FPIC might be incorporated in an existing World Heritage nomination process. Next, an overview is given of the social, cultural and political context of Cape York Peninsula and the progress of a current nomination process that incorporates 
Indigenous consent. Lastly, five major issues are discussed that arise from this literature and context: the notion of self-exclusion and initial engagement; the power of veto; representation and Indigenous ways of decision making; and notions of selfdetermination in FPIC processes.

How FPIC is defined is important to this discussion. The definition here is drawn from the United Nations Declaration on the Rights of Indigenous Peoples (United Nations 2007) and the 'International Workshop on Free, Prior Informed Consent and Indigenous People's (United Nations 2005). Contributions from Bass (2003), Tamang (2004) and Perault et al. (2007) are also included. Firstly, free means the absence of coercion and outside pressure, including monetary inducements (unless they are mutually agreed on as part of a settlement process), and divide and conquer tactics (Bass 2003). It must also include the absence of any threats or retaliation if it results in the decisions to say 'no' to proposals by proponents. Prior means a process taking place with sufficient lead time to allow the information gathering and sharing process to take place, including translations into traditional languages and verbal dissemination as needed, according to the decisionmaking processes decided by the Indigenous People involved. Consent must also take place without time pressure or time constraints. A plan or project must not begin before this process is fully completed and an agreement is reached (Perrault et al. 2006).

Next, informed means having all relevant information reflecting all views and positions is provided. This information includes the input of Traditional Elders, Spiritual Leaders, Traditional Subsistence Practitioners and Traditional Knowledge Holders, with adequate time and resources to find and consider information that is impartial and balanced as to potential risks and benefits to Indigenous People, based on the 'precautionary principle' (Vanclay 2003) regarding potential threats to health, environment or traditional means of subsistence (United Nations 2007). It also means that the information provided by the proponent is transparent and complete and that all their intentions and objectives are concise and clear. Finally, consent means the demonstration of clear and compelling agreement, using a mechanism to reach agreement which is in itself agreed to by Indigenous People under the principle of FPIC, in keeping with the decision-making structures and criteria of the Indigenous Peoples involved, including traditional consensus procedures (Tamang 2004). Agreements must be reached with the full and effective participation of the authorised leaders, representatives or decision-making institutions as decided by Indigenous People (United Nations 2009).

To summarise, the definition offered here is based on a philosophical approach of self-determination to FPIC and does not promote FPIC as just another form of consultation. It is this approach that is adopted in this research.

\section{Review of FPIC in the World Heritage processes}

FPIC has not yet been adopted by UNSECO's World Heritage Committee in their nomination procedures and management plans and monitoring of cultural and mixed sites (Disko 2010, United Nations 2011). This is despite the existence of considerable literature on the need for Indigenous consent in the planning and management of conservation areas (CBD 1996, IUCN 2003, Colchester 2004, DeRose 2004, Alcorn and Royo 2007, DeRose et al. 2007, Wild 2007, Larsen and Springer 2008, Colchester and Ferrari 2009, Krueger 2009, Wild and Mcleod 2009, Burhenne and 
Guilmin 2011). Furthermore, UNESCO's World Heritage Committee's Operational Guidelines for the Implementation of the World Heritage Convention (UNESCO 2011) do not include Indigenous consent in the nomination process (Disko 2010). However, there is acknowledgement of local people in cultural values assessment and their inclusion in management plans. The most relevant guidelines relating to consent are UNESCO's (2011, p. 90) Resource Manual for Preparing World Heritage Nominations, which asks nation states the question: '[d]oes the management plan/system involve stakeholders, especially property owners and managers, and is there strong support for the plan/system?' In this context, stakeholders include Indigenous People as well as other stakeholders. However, there is no statement that explicitly guides the use of consent in World Heritage nomination processes.

Furthermore, Indigenous consent is mentioned in the processes of ICOMOS when it assesses nomination during an on-the-ground visit for the Australian context. The Australian ICOMOS procedures indicate partial and implicit implementation of consent. The Australian ICOMOS Statement on Indigenous Cultural Heritage, adopted by the Executive Committee in 2001 (Australia ICOMOS Secretariat 2001, p. 1), says that '[I]ndigenous People must be effectively involved in decisions affecting their heritage, and in managing places significant to them. Land managers must respect the rights of Indigenous People to make decisions about their own Heritage.' This highlights the lack of formal acknowledgement of FPIC in World Heritage nomination processes. Additionally, ICOMOS officials judging nominations may include the concept of consent using a series of questions related to FPIC and management plans. These questions seek to ascertain the involvement in, and agreement to, Indigenous involvement in management of the nominated World Heritage area. These questions are not an officially documented series of questions that are asked of every nomination; rather, they represent an ad hoc approach based on the expertise and perspectives of the officials (Fowler 2001).

In brief, FPIC is lacking in current nomination processes and there are deficiencies from a procedural perspective (Disko 2010). The case for the inclusion of FPIC in World Heritage nomination processes is compelling. However, how FPIC could be adopted in the processes is yet to be developed. At present, there is little guidance on how to engage Indigenous People in participatory processes and it is up to the nation states to undertake this as they see fit within the broad parameters of UNESCO's guidelines. This is further exacerbated because of the contested notion of what natural and cultural landscape mean in terms of site World Heritage site assessments (Aplin 2007).

There are a range of actions that could incorporate the principles of FPIC in the process of nomination to ensure appropriate engagement of Indigenous People in the process of World Heritage nomination processes, as shown in Table 1 (Disko 2010). The main recommendations are to include Indigenous participation in all processes of the World Heritage convention, including nomination processes and management plans; and to ensure that sites are not listed unless there is free, prior and informed consent from Indigenous Peoples. These recommendations are commensurate with the Tenth Session of the United Nations Permanent Forum on Indigenous Issues (United Nations 2011) where Indigenous representatives from nation states called for UNESCO to incorporate FPIC into World Heritage nomination processes.

In brief, to help guide nation states in their engagement with Indigenous People, guidelines need to adopt an approach that conforms to the intent of the United Nations Declaration of the Rights of Indigenous Peoples (2007). FPIC should not 
Table 1. Recommendation for increasing Indigenous participation in UNESCO's World Heritage nomination and management procedures as proposed by Disko (2010).

- Formally commit to a human rights-based approach and endorse the UN Declaration on the Rights of Indigenous Peoples.

- Be more consistent and rigorous in ensuring effective Indigenous participation in all processes of the Convention (nomination processes, elaboration of management plans, site management, monitoring, etc.).

- Establish an Indigenous advisory body. The establishment of an Indigenous advisory body was first proposed in 2000 by the World Heritage Indigenous Peoples Forum in Cairns (Australia).

- Strengthen the provisions on community participation in the Operational Guidelines.

- Refrain from listing sites located in Indigenous territories without Indigenous Peoples' free, prior and informed consent.

- Refrain from listing sites in Indigenous territories as 'natural sites' and encourage the relisting of existing natural sites in Indigenous territories as "mixed sites" or cultural landscapes.

- Undertake a review of all World Heritage sites, with the full participation of Indigenous peoples, to identify shortcomings with regard to Indigenous rights.

be seen just simply as an innovative method of consultation in World Heritage nomination but an approach that acknowledges the inalienable rights of Indigenous People in determining how they may engage in a process about changes in the way their lands are managed. It should be also noted that in Australia, as elsewhere, noone interest group has complete right to determine how land is used. Given this context, the issue at hand is how recommendations such as these are applied. It was this question that the following Cape York case study addressed.

\section{Methodology}

The methodology employed in this study was case research. Case research has the capacity to account for complexity (Yin 2009), and the direct engagement of the researcher in that complexity. Case research has received growing attention because of a shift in the purpose of social research away from its predictive role towards an understanding of process (VanWynsberghe and Khan 2007) and the notion that the phenomenon under study cannot be separated from the context (Yin 2009). Two sources of data are used in the case research: documents and participant observation. A critical approach to analysing the case was used, with the international principles of consent used as a framework for the analysis.

A single case is an acceptable unit of research (Yin 2009). This single case may be exemplary (Yin 2009) and paradigmatic (Flyvbjerg 2006) where the case sets a new metaphoric agenda in the way things are conceived and actioned in the world. In the case of potential World Heritage nomination on Cape York Peninsula, the implementation of FPIC within this nomination process is likely to be breaking new ground. Even if the nomination cannot successfully attain Indigenous consent, the case is still important as an example of developing an FPIC process in future World Heritage nomination processes. Thus, the findings and conclusions of the single case will illuminate key issues relating to how FPIC can be incorporated into World Heritage nomination processes. 
The case research began with a review of literature to identify how elements of FPIC could be incorporated in existing World Heritage nomination processes. The paucity of scholarly literature critiquing the lack of FPIC World Heritage nomination processes limited this review in terms of the amount of peer-reviewed publications used to address the aims of the study. However, there are a growing number of non-peer-reviewed papers and online documents from interested stakeholders that publically call for an overhaul of the current system. Both these types of sources are used.

The researchers of this study were commissioned to write a report advising the Queensland Government where FPIC was previously used and suggest a process of negotiating Indigenous consent. The context of the case included most aspects of the nomination process in Cape York Peninsula. Understanding the social, political and cultural contexts of the Indigenous consent process in the potential nomination process was aided by the researchers being embedded in the case itself.

A layered account drawn from Ellis's (Ellis et al. 2010) work on auto-ethnography was used to focus the authors' experience of being engaged in the process of developing an FPIC process as part of the analysis of the issues involved. The use of vignettes, reflection and introspection aimed to document the researchers' experience doing and writing research simultaneously and provided a methodologically sound framework (Ellis et al. 2010). The outcomes of this research are in the form of offering suggestions with less emphasis on measures of truth (Ellis et al. 2010). An important part of communicating this type of research is acknowledging the position of the researcher. Therefore, the language used in this paper is first person to reflect the five authors' direct engagement in the research process.

\section{The Cape York Peninsula context and the research project}

The case examined was the use of FPIC in a potential World Heritage listing in Cape York Peninsula, Australia. It is located in the state of Queensland in the top north-east region of Australia. It extends north from a line between Cooktown on the east coast and Karumba on the Gulf of Carpentaria on the west coast to the tip of Cape York. Figure 1 shows Cape York and the location of Cape York Peninsula.

Cape York Peninsula is one of the few remaining landscapes in the world that is relatively untouched by human development (Valentine 2006). Much of the region has been identified as having Areas of International Conservation Significance under the Queensland's Cape York Heritage Act (Valentine 2006, Smyth and Valentine 2008). This identification, while not formally linked, is the precursor to the areas being nominated for World Heritage listing. Land that may be part of the potential nomination include existing National Parks which may also have indigenous land use agreements in place, Government leasehold land and Aboriginal land trusts. The boundaries have not been identified as this is part of the FPIC process adopted by the Queensland Government.

The current Australian and Queensland Government has been progressing the case for World Heritage nomination for certain areas of Cape York Peninsula. As part of this agenda an agreement between various stakeholders to proceed with preparations for World Heritage nomination has been spelt out in the Cape York Heads of Agreement in 1996. The agreement was signed by the Cape York Land Council and the Peninsula Regional Council of the Aboriginal and Torres Strait Islander Commission, representing traditional Aboriginal owners on Cape York 


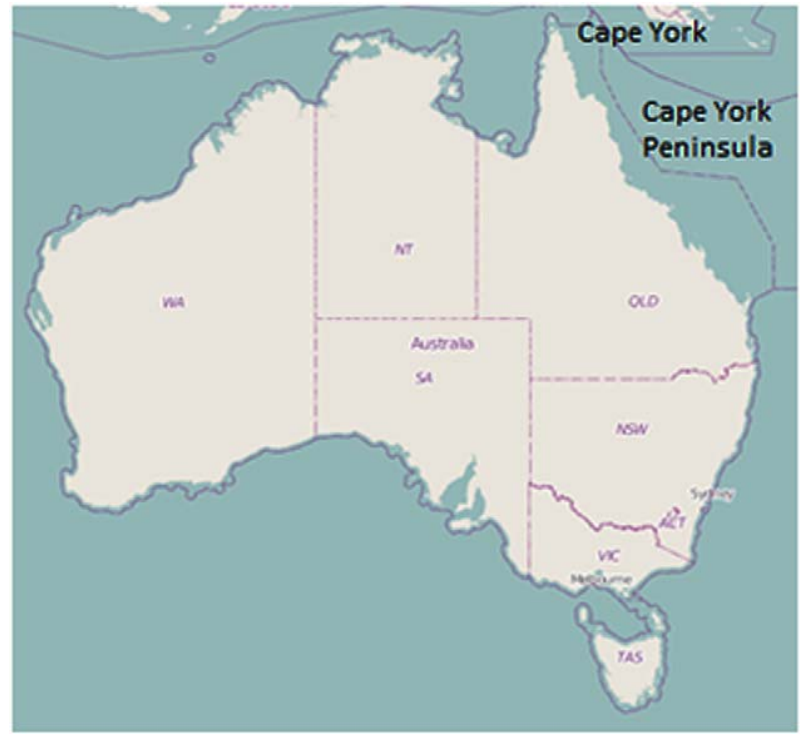

Figure 1. Map of Australia indicating Cape York Peninsula.

Peninsula, and the Cattlemen's Union of Australia Inc., the Australian Conservation Foundation and The Wilderness Society. Of relevance to the Indigenous consent to World Heritage is the agreement that " $[\mathrm{t}]$ he nomination for World Heritage listing on any land on Cape York Peninsula shall proceed only where there is a management arrangement which is negotiated with all landholders who may be affected directly by such listing' (Cape York Heads of Agreement 1996, p. 1). As a result of this agreement the Queensland's Cape York Heritage Act was legislated in 2007. Two committees (Cape York Peninsula Regional Advisory Committee and the Cape York Region Scientific and Cultural Advisory Committee) have been established to advise the Queensland Government on the process of World Heritage nomination. The Cape York Peninsula Regional Advisory Committee is an advisory committee with $50 \%$ of its membership being Indigenous People from the region. However, the membership is ultimately determined by the Government and so is not a directly democratic process. This feature calls into question the representativeness of this committee to speak on behalf of all Indigenous People affected by the potential listing.

The Cape York Peninsula context is complex and contested (Holmes 2011). There are over 100 Traditional Owner clan groups on Cape York Peninsula, located within 17 Indigenous Communities and represented by 11 local government authorities. The Cape York Land Council is the peak representative body that represents Indigenous People in their land rights claims and other Indigenous matters. Over 70 Land Trusts and Prescribed Body Corporate organisations have been established in Cape York Peninsula. The Aboriginal and Torres Strait Islander People make up over $60 \%$ of the total population of 18,000 people. Aboriginal people's language, dance, song, art and customs are still very much alive and practised, and vary from community to community (Batzke and Talbot 2010).

Indigenous consent to World Heritage has become a political prerequisite for the nomination to proceed. The Queensland Government and the Australian Federal 
Government have indicated the importance of the consent of Indigenous People and have stated that a nomination will not proceed without the consent of Traditional Owners. ${ }^{1}$ The current Australian Government stated that they will seek the consent from Indigenous People and nominate certain areas of Cape York Peninsula for World Heritage listing before the end of their term in government. This gave the Government a period of approximately two years to negotiate Indigenous consent to enable nomination to be submitted to UNESCO.

Unlike previous nominations the reason why consent of Indigenous People for World Heritage nomination in Cape York Peninsula has been elevated beyond what is currently expected by the guidelines of UNESCO has resulted from other issues impacting on the nomination process. The Cape York Land Council, just prior to the project commencing, indicated that they do not support World Heritage nomination and any process of developing methods of negotiating Indigenous consent, until issues pertaining to Wild Rivers legislation are resolved to their satisfaction (Ah Mat 2001). The Wild Rivers legislation is a conservation law that controls the development along rivers in the state of Queensland. Some Indigenous groups are publically campaigning against this law because they see it taking away the rights of Indigenous People from self-determined development.

Despite not having support from the Cape York Land Council, one of the key Indigenous representative organisations, the Queensland Government is proceeding with negotiations for World Heritage nomination. The issue of the Cape York Land Council not being included is discussed below in the section on preconditions and self-exclusions. An initiative called a Country-Based Planning Approach to Traditional Owner Engagement (Queensland Government 2011) has been adopted by the Queensland Government for the purposes of negotiating the first stage of consent from Traditional Owners for World Heritage nomination. This approach aims to undertake cultural mapping with Traditional Owners after consultation and cooperation with the local Indigenous organisations such as land trusts, local shire councils and other locally relevant Indigenous organisations. The Queensland Government has stressed that consent to undertake cultural mapping does not imply consent to World Heritage nomination.

The researchers' engagement in the research on developing and advising the Queensland Government on a consent process appropriate for Cape York context was conditional on the engagement of the Cape York Land Council being involved in that process. However, after formal engagement of the researchers by the Queensland Government, the Cape York Land Council withdrew their informal agreement to participate in the development of a consent process, as noted above. As a consequence of the contractual commitments, the researchers were legally compelled to continue with the research project. The withdrawal of the Cape York Land Council (CYLC) created a dilemma because fundamental to developing a consent process is the participation of Indigenous representative organisations. Without the CYLC participation the researchers' advice to the Queensland Government would lack Indigenous input in the research process. Accordingly the overall process of the developing a consent framework representing all views was limited. In summary, we are aware of the political nature of research and agree with (Smith 1999 , p. 5) who says that research is linked to its social context - 'research is not an innocent or distant exercise but an activity that has something at stake and that occurs in a set of political and social conditions'. 


\section{Issues of FPIC and World Heritage nomination}

In brief, not only does FPIC need to be included in World Heritage nomination processes, but the philosophical and practical issues that emerge from the ambiguities of the implementation of FPIC principles also need to be addressed. Simply adopting the principles from the UN Declaration of the Rights of Indigenous People will not necessarily lead to the realisation of the rights from the declaration. As the United Nations Expert Mechanism on the Rights of Indigenous Peoples (United Nations 2010a, 2010b) reported, the outcomes of FPIC have been limited despite the principle of FPIC being endorsed by a large number of nation states and implemented in a number of situations within those nations in various contexts. Thus, the issues of how FPIC is implemented in the context of a World Heritage listing, like the Cape York case, need to be addressed: self-exclusion; representation and Indigenous ways of decision making; the power of veto and self-determination.

\section{Self-exclusion}

Self-exclusion from the process of consultation has the effect of ensuring groups are kept off limits to the process of engagement initiated by proponents (Dryzek 2002). Keeping outside the realm of initial negotiations is a way of keeping options open (Dore and Lebel 2010). The motivation for self-exclusion may also stem from a perception by Indigenous People that outcomes of the process have already been decided prior to engagement in an FPIC process.

In the case of the potential World Heritage nomination of certain areas of Cape York Peninsula, one of the key representative bodies, the Cape York Land Council, did not engage in the early stages of developing the FPIC process in potential nomination (Ah Mat 2001). Our understanding of the reasons for self-exclusion was because the national and state governments had made promises to gain consent from Indigenous People and this had the effect of affording power to this organisation and thus they used this as a point of leverage to resolve their concerns about the issue of the Wild Rivers legislation. Attending to preconditions that allow for a consent process to start successfully in the first place is an important feature of FPIC and the nomination process. Despite the potential use of FPIC as a point of leverage, if FPIC is implemented as a principle in World Heritage nomination processes the likelihood of self-exclusion from the process of nomination by Indigenous representative organisations and individuals is less because there is greater trust placed in a formal process than a consent process based on political promises of the nominating country.

\section{Representation and Indigenous ways of decision making}

The United Nations Declaration of the Rights of Indigenous People (2007) outlines how the principles of FPIC should be implemented but due to the generality of the principles there are two points that need further exploration. Firstly, there is the issue of representation and next is the problem of the decision-making process of consent itself which relates to the meaning and action of consent.

The United Nations Declaration of Indigenous People (2007) leans towards more collective forms of consent. The issue of representation as outlined in Articles 18 and 19 of the United Nations Declaration of Indigenous People (2007) states that Indigenous People need to choose their own representatives to be part of the FPIC 
process and that the representative organisations need to give consent to the proposal. Importantly, in the drafting of the Declaration, Indigenous People from a large number of nations lobbied for consent being conceived as a collective decision by Indigenous Peoples and not one where consent was to be understood as an agreement by an individual Indigenous person only (Gilbert and Doyle 2011). However, the balance between Traditional Owners and collective consent through representative bodies, community referendums and or other survey techniques as required for FPIC in any potential World Heritage nomination will need to be considered on a case-by-case basis.

In the case of Cape York Peninsula, there are significant issues of representation that need to be addressed, and it is unclear from existing UNESCO literature how to determine representation. If nomination were to proceed, the Traditional Owners of particular lands would need to give consent as well as a range of other representative bodies including the representative land council, in this case the Cape York Land Council. However, a situation may occur where the Cape York Land Council does not ultimately give consent but a critical mass of Traditional Owners may give consent to enough land to satisfy the criteria of natural and cultural values for World Heritage and thus nomination might proceed on this basis. However, the validity of a nomination proceeding without consent of a range of representative organisations may be questioned under the present system of evaluation. Despite no mention of the need for Indigenous representation in the consultation process of nominations in the operational guidelines for World Heritage, the Australian ICOMOS statement on Indigenous Cultural Heritage makes reference to Indigenous People being effectively involved in decision making. Additionally, the IUCN's guidelines for protected area managers (Wild and McLeod 2009) suggest that consultation with Indigenous People concerning any proposed initiative will necessitate the meaningful participation of indigenous peoples and their representative institutions. This guideline is relevant because the evaluation of a nomination involving cultural heritage will be carried out by ICOMOS in consultation with the IUCN.

One of the reasons for stressing the need for representation is that these organisations can negotiate initiatives, programmes and strategies related to World Heritage listing. That is, adopting an approach to consent that focuses on Traditional Owners only, negates the broader issues of the impact of World Heritage listing at the regional level. Given the geographical extent of the potential nomination, a regional perspective on consent and the benefit sharing is important and thus consent from a range of representative bodies are needed.

In brief, in the development of FPIC processes, Indigenous People and their representatives need to have a central role in developing and implementing the actual consent process (McGee 2009). How this is developed may be best determined by input from a range of representative organisations in consultation with the Queensland Government.

In addition, the predominant system of decision making within groups of Indigenous People is a style of consensus decision making as opposed to democratic decision-making systems that are favoured in western societies (Burchill 2004). This means that consent from Traditional Owners is a process that usually takes longer than expected from non-Indigenous perspectives, because all individuals who have claim to country will need to give consent (or not) to be included in the nomination. Consent is needed also from Indigenous People on management plans and other planning arrangements. Indigenous ways of decision making also influence 
the contractual nature of consent because the representative(s) of the family/clan group would likely be the signatory of any consent 'contract' that legally legitimises consent to nomination. On this basis considerably more time is needed to reach contractual agreements.

\section{The power of veto}

The capacity to say no is important in processes of FPIC. The power of veto is a pivotal aspect of the participatory processes of assessment and negotiation of Indigenous People's engagement in an FPIC process. This is because the process of negotiating consent through FPIC is only valid if the parties recognise that a participatory options assessment over a specific project will not guarantee that an agreement will be reached at the end of the process (Mehta and Stankovitch 2001). However, there are limited cases of where veto power has been formalised in FPIC processes despite its acknowledgement as being central to Indigenous participation (McGee 2009). One of the reasons for not formalising veto power is that proponents do not wish to 'give' away power in the negotiating arena (McGee 2009).

Indigenous groups may be more willing to engage in FPIC negotiation if they have the capacity to exercise greater power. The example of the Aboriginal Land Rights Act 1976 (Commonwealth) in Australia is often used as an example of how power of veto can be exercised in the consent process by native title groups (Bass 2003, MacKay 2004, Page 2004, Perrault et al. 2006). In Cape York Peninsula, Indigenous People may be free to engage in consent processes for the potential World Heritage nomination process, but there is uncertainty over the legitimacy of current veto powers. To date, consent veto power is derived from two sources. The first source is from statements by Federal and Queensland State politicians who indicate that nomination will only proceed if consent is given by Indigenous people. These promises are valid only if succeeding politicians maintain these promises.

The second source is the non-statutory Cape York Heads of Agreement (1996) between a range of stakeholders (including the Cape York Land Council) which states that ' $[\mathrm{t}]$ he nomination for World Heritage listing on any land on Cape York Peninsula shall proceed only where there is a management arrangement which is negotiated with all land holders who may be affected directly by such listing' (Cape York Heads of Agreement 1996, p. 2). Despite this agreement, there is evidence that inclusion in World Heritage Area management plans does not necessarily mean the rights of Indigenous People's will be taken into account. For example, ongoing significant governance issues that relate to the inclusion of Indigenous interests in management still occur in Kakadu National Park (Haynes 2009) and in the Wet tropics (Hill 2006, Larsen and Pannell 2006).

Thus, legislation that acknowledges of power of veto is vital to enact FPIC (Carino 2005). Although not directly stated in the United Nations Declaration on the Rights of Indigenous People (2007), the intent of formalising veto power is acknowledged to the extent that it does not override the power of the state. Article 38 states that the 'States in consultation and cooperation with Indigenous Peoples, shall take the appropriate measures, including legislative measures, to achieve the ends of this Declaration' (United Nations 2007).

If FPIC and the power of veto are eventually included in World Heritage nomination processes, it also needs to be introduced into national legislation. For example, in Australia the management plans for a potential World Heritage Areas do 
not need to be legislatively approved until formal nomination has taken place. Although as part of World Heritage nomination processes, the indicative management plans need to be presented but the final operational plans will be developed once nomination is approved. This may lead to certain rights not being implemented in practice. Thus, if power of veto is included in the legislation of a nation that was submitting a nomination this would elevate the power of Indigenous People in the negotiation of management plans and other benefits that may be associated with World Heritage nomination prior to formal approval of World Heritage Listing. In the present case, this is acknowledged in the Cape York Heritage Act (2007) to some extent. The Act also indicated that other stakeholder interests need to be included in consultation processes and this suggests that if veto power is introduced under FPIC then other interests need to be accommodated within such a process.

If FPIC is not included in UNESCO World Heritage guidelines for nomination in the future, then the need for legislation with nation states is even more important. Such is the case for the potential nomination in Cape York Peninsula. Enshrining political intent into a legislative obligation would be a ground-breaking move in the history of FPIC in World Heritage nomination procedures and would contribute to ameliorating concerns that Indigenous People may have about initial engagement in the process of consent in the potential World Heritage nomination of certain areas of Cape York Peninsula. It is important to ensure Indigenous People have power in negotiations because there is limited historical evidence in Australia of positive economic benefits to Indigenous People arising from World Heritage listing in Australia (Zeppel 2002) and limited economic benefits generally from World Heritage listing in Australia (Buckley 2002). Questions over the negative social impacts of World Heritage Listing on Indigenous People have also been highlighted (West et al. 2006, Landorf 2009, Jimura 2011).

\section{Self-determination}

Self-determination in FPIC is a vital component in the development of consent process for World Heritage nomination guidelines. The implication related to the previous five issues is that if self-determination is elevated as a philosophy underpinning FPIC, then much of the problems associated with implementing FPIC in guidelines for World Heritage nomination will be reduced. The consensus from Indigenous representatives and advocates for FPIC in World Heritage nomination processes is that the power to give consent to proposals and projects should be sourced in the notion of self-determination (United Nations 2011). Self-determination does not necessarily mean that Indigenous People will use it as a secessionist vehicle. It is a principle in which the legal status and rights of Indigenous People are decided by the state with the participation and consent of Indigenous People (Lam 2000).

Justification for self-determination in FPCI processes is sourced from Article 3 of the United Nations Declaration on the Rights of Indigenous Peoples which states that ' $[\mathrm{I}]$ ndigenous Peoples have the right to self-determination. By virtue of that right they freely determine their political status and freely pursue their economic, social and cultural development' (United Nations 2007, p. 3). Thus, self-determination, not FPIC, is the starting point for the consultation process because FPIC is just a derivative of the right to self-determination (Puno and Laya 2007).

The adoption of self-determination as a philosophical approach is more aligned with a transformative and participatory planning than institutional approaches. 
Transformative and participatory approaches are understood as a planning method that is reflexive to community capacity, utilising new technologies of planning and acknowledgement of difference between communities and has the potential to decentralise and afford more power to Indigenous People compared to the more common institutional approach to governance of Indigenous communities and their interests (Lane 2002, Hibbard and Lane 2008). In the case of Cape York Peninsula, the general approach to planning for negotiating consent as part of the early stages of the nomination procedure for potential listing has leant towards an institutional approach as opposed to a transformative or participatory approach. Despite the institutional approach having the advantage of appearing to be more rapid, this approach tends to trigger reactions from a range of stakeholders because it neglects critical aspects of public participation (Lane 2002). If FPIC is to be true to the United Nations Declaration on the Rights of Indigenous Peoples and the intent of FPIC then the timelines should not dictate the planning approach to developing a process of consent and then negotiating consent. The time-intensive nature of the transformative or participatory approach means that the Federal Government and the Queensland will have difficulty implementing this approach because of election commitments that force the deadline for nomination of World Heritage on Cape York Peninsula. In any case, where institutional approaches have been used where more participatory approaches are more appropriate, the result has led to more agitation and resistance by Indigenous People (Lane and Hibbard 2005).

The result of a predetermined period to negotiate consent combined with an apparent bias towards an institutional approach may create the impression that an implied consent has been achieved during negotiations. Implied consent occurs when Indigenous People engage in the FPIC process itself and the terminology of 'consent' actually leads both proponents and Indigenous People towards the point of agreement:

[T] he usage of terminology which leads us to think and behave in such a way that we have no option but to accept what is proposed to us should not be permitted. As such, the processes between consultants and Indigenous Peoples should not be described as FPIC processes, but as self-determination, thus making it clear that the options of saying yes or no are possible and valid. (Puno and Laya 2007, p. 5)

While engaged in this research project, we concluded that the term 'FPIC' may not fully articulate the principle of self-determination in the practice of FPIC despite our acknowledgement of the inclusion of the principle in FPIC literature. Although not advocating for a change in nomenclature, we coined the term 'self-determined informed consent' during the research project because it emphasised one of the major intentions of FPIC. This emphasis ensures the purpose of FPIC is one of a process of engagement that affords greater power to Indigenous People in negotiations.

This section has presented a number of issues through the analysis of potential usage of FPIC in World Heritage nomination procedures. Preconditions may surface in potential nominations because the power that veto provides is a means for leverage of other issues as part of nomination processes. Issues of representation will also be a perennial concern in negotiating consent in nominations as well as the nature of Indigenous People's way of decision making. The transformative potential of an approach where the principle of self-determination is prioritised in FPIC faces a 
number of challenges in the present context of the potential Cape York nomination. This is not to say that it is not possible for this philosophical approach of FPIC to be prioritised in the current World Heritage nomination process. Finally, the issues identified in the context of the present potential nomination are likely to be present in other future nominations even if UNESCO adopts FPIC as a condition and guiding principle in the operational guidelines for World Heritage nomination. Negotiation of FPIC in future processes of nomination, with or without UNESCO guidelines, will need the active involvement of Indigenous Peoples' to ensure the intentions of the United Nations declaration of the Rights of Indigenous People are upheld.

Future research on the role of representative bodies in the consent process is needed to ensure that the process of negotiating consent conforms to the intent of the United Nations Declaration on the Rights of Indigenous Peoples (2007). Research examining how collective approaches to consent is sought and given is needed in order to resolve issues of Indigenous People's right to self-determination in UNESCO's World Heritage Committee nomination process.

\section{Conclusion}

This paper identified the current status of FPIC in relation to World Heritage nomination processes and explored some of the issues that arise when FPCI is adopted as a framework for Indigenous consent to World Heritage nomination in an Australian context. This paper aimed to identify how elements of FPIC can be incorporated in existing World Heritage nomination processes. Five issues were identified as being relevant to the case of potential World Heritage Listing of certain areas of Cape York Peninsula.

The first issue was concerned with preconditions and self-exclusion. In the case of preconditions affecting initial engagement, if FPIC is adopted in the process of nomination, then self-exclusion can be envisaged as a source of power to ensure the nomination process is a robust one. If FPIC is used the power to negotiate on other pre-existing issues outside the realm of the nomination process is possible. The second issue was the nature of consent and it was found to be problematic from two perspectives. The first of these is that consensual decision-making system that needs to be formalised into a contractual agreement between Traditional Owners and the state - this is time consuming and will vary depending on the context of each nomination. The second of these is the negotiation of consent by the Indigenous representative organisations needs to be undertaken and formalised in a way that recognises the legitimate power of their representation. The third is that traditional ways of decision making and the time needed to do so also need to be acknowledged during the consent process. The fourth issue analysed was the power of veto and how nation states should consider strengthening their own legislation that enshrines FPIC as a condition for nomination. This would enact planning procedures that involve Indigenous People in the development of management plans and other initiatives associated with World Heritage listing.

The resolution of these issues will be more likely if the philosophy of selfdetermination is adopted as a central feature of the nomination process. From this perspective, we argued for self-determination to be prioritised in FPIC processes so that the intent of the consent process is shifted from one of simply ensuring Indigenous People are engaged appropriately by the 'proponent' to one which has Indigenous People themselves at the forefront of deciding potential World 
Heritage Area management arrangements. Irrespective of FPIC's incorporation into World Heritage nomination procedures the case of Cape York has shown that a potential nomination can include consent as a framework for negotiating Indigenous People's involvement but that issues of engagement in that process need to be resolved in order to ensure the intent of United Nations declaration of the Rights of Indigenous People is upheld.

\section{Notes an contributors}

Robert Hales lectures in the Department of Tourism Leisure Hotel and Sport Management at Griffith University, Australia. His research interests centre on public involvement in the governance of environment issues in protected areas. His recent projects include building capacity for Indigenous engagement in climate change adaptation in Australia.

John Rynne is a member of the Key Centre for Ethics Law Justice and Governance at Griffith University, Australia. His primary research interests are in social justice issues relating to Australian Indigenous people.

Dr. Cathy Howlett is currently lecturing in Anthropology and Development Studies at Griffith University in the School of the Environment. Her research foci include the political economy aspects of resource development in Indigenous domains, with a distinct emphasis on developing appropriate theoretical explanations of the relationship between Indigenous Australians and the Australian state in relation to resource development.

Jay Devine is a researcher employed at Griffith University, Australia. Her background includes work with Indigenous people to develop Indigenous Land Use Agreements for various governments in Australia.

Vivian Houser is a PhD student and is a researcher employed at Griffith University, Australia.

\section{Note}

1. On 25 February 2010, Minister for the Environment Peter Garrett stated that 'The government has always made it perfectly clear that any negotiations going forward in terms of tentative listing are dependent upon the full consent and participation of Indigenous People in Cape York'. (Hansard, 25 February 2010); On the 9th of February Queensland's Sustainability Minister Kate Jones also confirmed the Queensland Government's commitment to indigenous consent by stating 'We will not proceed with a formal World Heritage nomination without the express and informed consent of Traditional Owners'. (AAP, 9 February 2010); On 8th of September, 2011 Tony Burke, the Australian Minister for the Environment, said that his government had a 'clear commitment that a World Heritage nomination would not proceed without the prior consent of Traditional Owners' (Burke, September, 2011).

\section{References}

Ah Mat, R., 2001. Pearson and Ah Mat warn Minister their support is not guaranteed yet. National Indigenous Times [online]. Available from: http://www.nit.com.au/news/story. aspx?id=22767 [Accessed July 2011]. 
Alcorn, J. and Royo, A., 2007. Conservation's engagement with human rights: 'Traction,' 'slippage,' or avoidance. Policy Matters, 15, 115-139.

Aplin, G., 2007. World Heritage cultural landscapes. International Journal of Heritage Studies, 13 (6), 427-446.

Australia ICOMOS Secretariat, 2001. Australia ICOMOS statement on indigenous culturalheritage [online]. Available from: http://australia.icomos.org/wp-content/uploads/Australia-ICOMOS-Statement-on-Indigenous-Cultural-Heritage.pdf [Accessed June 2011].

Bass, S., 2003. Prior informed consent and mining: promoting the sustainable development of local communities. Canberra: Environmental Law Institute.

Batzke, Y. and Talbot, L., 2010. Indigenous engagement framework. A report to the Cape York Peninsula Regional Advisory Committee and the Cape York Peninsula Region Scientific and Cultural Advisory Committee.

Berkes, F., 2009. Evolution of co-management: role of knowledge generation, bridging organizations and social learning. Journal of Environmental Management, 90 (5), 1692-1702.

Borrini-Feyerabend, G. Johnston, and Pansky, D., 2006. Governance of protected areas. In: M. Lockwood, G. Worboys, and A. Kothari, eds. Governance of protected areas, managing protected areas: a global guide. London: Earth Scan, 116-145.

Brosius, J., 2004. Indigenous peoples and protected areas at the World Parks Congress. Conservation Biology, 18 (3), 609-612.

Buckley, R., 2002. World Heritage icon value: contribution of World Heritage branding to nature tourism. Canberra: Australian Heritage Commission.

Burchill, M., 2004. Enough talking - more walking: achieving more deadly outcomes. Stronger Families Learning Exchange Bulletin, 6 (Spring/Summer), 6-9.

Burhenne, B. and Guilmin, F., 2011. Guidelines for protected areas legislation. Gland: World Conservation Union.

Cape York Heads of Agreement, 1996. Cape York Heads of Agreement as documented by the Queensland Government [online]. Available from: http://www.derm.qld.gov.au/services_resources/item_details.php?item_id=206905 [Accessed July 2011].

Cape York Heritage Act 2007. Act No. $\overline{48}$ of year 2007 Available from: http://www.legislation.qld.gov.au/LEGISLTN/ACTS/2007/07AC048.pdf [Accessed July 2011].

Carino, J., 2005. Indigenous Peoples' right to free, prior, informed consent: reflections on concepts and practice. Arizona Journal of International \& Comparative Law, 22 (1), 19-39.

CBD 1992. Convention on biological diversity. Rio de Janeiro, 5 June 1992 Available from: http://www.cbd.int/convention/text/ [Accessed July 2011].

CBD, 1996. Convention on biological diversity [online]. Available from: http://www.cbd.int/ convention/text/ [Accessed July 2011].

Colchester, M., 2004. Conservation policy and Indigenous Peoples'. Environmental Science \& Policy, 7 (3), 145-153.

Colchester, M., and Ferrari, M., 2009. Making FPIC-free, prior and informed consent-work: challenges and prospects for Indigenous, Forest Peoples Programme [online]. Available from: http://www.forestpeoples.org [Accessed July 2011].

Colchester, M., et al., 2008. Conservation and Indigenous Peoples: assessing the progress since Durban. Interim Report: Forest Peoples Programme.

Derose, A., 2004. Overview of community participation at the Vth IUCN World Parks Congress. Protected Areas Programme Vth IUCN World Parks Congress.

Disko, S., 2010. World Heritage Sites in Indigenous Peoples' territories: ways of ensuring respect for Indigenous cultures, values and human rights. Bonn: World Heritage and Cultural Diversity.

Dore, J. and Lebel, L., 2010. Gaining public acceptance: a critical strategic priority of the World Commission on Dams. Water Alternatives, 3 (2), 124-141.

Dryzek, J., 2002. Deliberative democracy and beyond: liberals, critics, contestations. New York, NY: Oxford University Press.

Ellis, C., Adams, T., and Bochner, A., 2010. Autoethnography: an overview. Qualitative Social Research, 12 (1), [online]. Available from: http://www.qualitative-research.net/ index.php/fqs/article/view/1589/3095 [Accessed June 2011].

Flyvbjerg, B., 2006. Five misunderstandings about case study research. Qualitative Inquiry, 12 (2), 219-245. 
Fowler, P., 2001. World heritage cultural landscapes, 1992-2002: a review and prospect. In: UNESCO World Heritage paper 7 - Cultural landscapes: The challenges of conservation. Paris: UNSCO.

Gilbert, J. and Doyle, C., 2011. A new dawn over the land: shedding light on collective ownership and consent. In: S. Allen and A. Xanthaki, eds. Reflections on the UN declaration on the rights of Indigenous Peoples. Studies in International Law. Oxford: Hart.

Haynes, C., 2009. Defined by contradiction: the social construction of Joint Management in Kakadu National Park. Thesis (PhD). Darwin: Charles Darwin University.

Hibbard, M. and Lane, M., 2008. The split personality of planning. Journal of Planning Literature, 23 (2), 136-151.

Hill, R., 2006. The effectiveness of agreements and protocols to bridge between Indigenous and non-Indigenous toolboxes for protected area management: a case study from the Wet Tropics of Queensland. Society \& Natural Resources: An International Journal, 19 (7), 577-590.

Holmes, J., 2011. Contesting the future of Cape York Peninsula. Australian Geographer, 42 (1), 53-68.

IUCN, 2003. World Parks Congress in Durban, Recommendation 14 [online]. Available from: http://cmsdata.iucn.org/downloads/recommendationen.pdf [Accessed July 2011].

IUCN, 2008. World Conservation Congress: resolutions and recommendations of the IUCN WCC. Indigenous Peoples' rights in the management of protected areas fully or partially in the territories of Indigenous Peoples [online]. Available from: http://intranet.iucn.org/ webfiles/doc/IUCNPolicy/Resolutions/2008_WCC_4/English/REC/rec_4_127_indigenous peoples_rights_in_the_management_of_protected_areas_fully_or_partially_in_the_territories_of_indigenous_peoples.pdf [Accessed July 2011].

Jimura, T., 2011. The impact of world heritage site designation on local communities - a case study of Ogimachi, Shirakawa-mura, Japan. Tourism Management, 32 (2), 288-296.

Krueger, L., 2009. Protected areas and human displacement: improving the interface between policy and practice. Conservation Society, (7), 21-25.

Lam, M., 2000. At the edge of the state: Indigenous Peoples and self-determination. New York, NY: Transnational, Ardsley.

Landorf, C., 2009. Managing for sustainable tourism: a review of six cultural World Heritage Sites. Journal of Sustainable Tourism, 17 (1), 53-70.

Lane, M., 2002. Buying back and caring for country: institutional arrangements and possibilities for Indigenous lands management in Australia. Society \& Natural Resources: An International Journal, 15 (9), 827-846.

Lane, M. and Hibbard, M., 2005. Doing it for themselves. Journal of Planning Education and Research, 25 (2), 172-184.

Langton, M., Rhea, M., and Palmer, L., 2005. Community-oriented protected areas for Indigenous Peoples and local communities. Journal of Political Ecology, 22 (12), 23-50.

Larsen, L. and Pannell, S., 2006. Developing the Wet Tropics Aboriginal Cultural and Natural Resource Management Plan. Cairns: Cooperative Research Centre for Tropical Rainforest Ecology and Management.

Larsen, P.B. and Springer, J., 2008. Mainstreaming WWF principles on Indigenous Peoples and conservation in Project and Programme Management. Washington, DC: WWF.

Lockwood, M., 2010. Good governance for terrestrial protected areas: a framework, principles and performance outcomes. Journal of Environmental Management, 91 (3), 754-766.

McGee, B., 2009. Community referendum: participatory democracy and the right to free, prior and informed consent to development. The Berkeley Journal of International Law, 27 (2), 570-635.

Mehta, L. and Stankovitch, M., 2001. Operationalisation of free prior informed consent, Contributing paper to the World Commission on Dams.

Perrault, A., Herbertson, K., and Lynch, O., 2006. Partnerships for success in protected areas: the public interest and local community rights to prior informed consent (PIC). Georgetown International Environmental Law Review, 19, 475-521.

Perrault, A., Herbertson, K., and Lynch, O., 2007. Partnerships for success in protected areas: the public interest and local community rights to prior informed consent 19 Georgetown. International Environmental Law Review, 19 (3), 475-542. 
Puno J. and Laya, O., 2007. Starting point: self-determination, a peruvian case study [online]. Forest Peoples Programme. Available from: http://www.forestpeoples.org/sites/ fpp/files/publication/2010/08/fpicperu07eng.pdf [Accessed July 2011].

Queensland Government, 2011. Country based planning approach to traditional owner engagement, Discussion Paper. Brisbane: Queensland Government, 2011.

Schmidt-Soltau, K. and Brockington, D., 2007. Protected areas and resettlement: what scope for voluntary relocation? World Development, 35 (12), 2182-2202.

Smith, L., 1999. Decolonizing methodologies: research and Indigenous Peoples. London: Zed Books.

Smyth, D. and Valentine, P., 2008. Pathways: a draft Discussion Paper to securing cultural and natural heritage of International Conservation Significance on Cape York Peninsula. Developed in consultation with the Cape York Peninsula Scientific and Cultural Advisory Committee, the Cape York Peninsula Regional Advisory Committee and the Australian Government. Brisbane: Queensland Government.

Tamang, P., 2004. An Overview of the Principle of Free, Prior and Informed Consent and Indigenous Peoples in International and Domestic Law and Practices, UN Workshop on Free, Prior and Informed Consent, PFII/2004/WS.2/8. Available from: http://www.un. org/esa/socdev/unpfii/documents/workshop_FPIC_tamang.doc [Accessed July 2011].

UNSECO, 2011. The operational guidelines for the implementation of the world heritage convention. Available from: http://whc.unesco.org/en/guidelines [Accessed July 2011].

United Nations, 2005. International Workshop on Free Prior and Informed Consent and Indigenous Peoples. New York, NY: Secretariat of the Permanent Forum on Indigenous Issues.

United Nations, 2007. The UN declaration on the rights of Indigenous Peoples [online]. New York, NY: United Nations. Available from: http://ww.un.org/esa/socdev/unpfii/en/ drip.html. [Accessed August 2011].

United Nations, 2009. The UN Declaration on the rights of Indigenous Peoples, Treaties and the right to free prior and informed consent: the framework for a new mechanism for reparations, restitution and redress. New York, NY: United Nations.

United Nations, 2010a. Progress Report on the Study on Indigenous Peoples and the right to participate in decision-making: report of the expert mechanism on the rights of Indigenous Peoples. New York, NY: United Nations Human Rights Council, Fifteenth Session, Item 5.

United Nations, 2010b. Report of the Expert Mechanism on the Rights of Indigenous Peoples on its third session. Chairperson-Rapporteur: José Carlos Morales. New York, NY: United Nations Human Rights Council, Fifteenth Session, Item 5.

United Nations, 2011. Permanent forum on Indigenous issues tenth session $3 \mathrm{rd} \& 4$ th meetings [online]. Available from: http://www.un.org/News/Press/docs//2011/hr5053.doc.htm [Accessed August 2011].

Valentine, P., 2006. Compiling a case for World Heritage on Cape York Peninsula. A report to the Queensland Environmental Protection Agency. Brisbane: Queensland Government.

Vanclay, F., 2003. International principles for social impact assessment. Impact Assessment and Project Appraisal, 21 (1), 5-12.

VanWynsberghe, R., and Khan, S., 2007. Redefining case study. International Journal of Qualitative Methods, 6 (2), Article 6. Available from: http://www.ualberta.ca/ iiqm/backissues/6_2/vanwynsberghe.htm [Accessed July 2011].

West, P., Igoe, J., and Brockinton, D., 2006. Parks and peoples: the social impact of protected areas. Annual Review of Anthropology, (35), 251-277.

Wild, R., 2007. IUCN-UNESCO guidelines for protected area managers on sacred natural sites: rationale, process and consultation. The Sacred Dimension of Protected Areas. Ouranoupolis: Proceedings of the Second Workshop of the Delos Initiative.

Wild, R. and McLeod, C., 2009. Sacred natural sites: guidelines for protected area managers. Best Practice Protected Area Guideline 16, World Conservation Union.

Yin, R., 2009. Case study research: design and methods. Thousand Oaks, CA: Sage.

Zeppel, H., 2002. Indigenous tourism in the Wet Tropics World Heritage Area, North Queensland. Australian Aboriginal Studies, 2, 65-68. 